\title{
Fortification of Rice Noodles with Vitamin A: Quality, Sensory Evaluation, and Enhancement of Vitamin A Intakes
}

\author{
Nura MALAHAYATI ${ }^{1}$, Kharidah MUHAMMAD ${ }^{2}$, Jamilah BAKAR ${ }^{3}$ and Roselina KARIM ${ }^{3}$ \\ ${ }^{1}$ Department of Agricultural Technology, Faculty of Agriculture, Sriwijaya University, \\ Palembang, South Sumatera, Indonesia \\ ${ }^{2}$ UPM-BERNAS Research Laboratory, Faculty of Food Science and Technology, \\ Universiti Putra Malaysia, Selangor, Malaysia \\ ${ }^{3}$ Department of Food Technology, Faculty of Food Science and Technology, \\ Universiti Putra Malaysia, Selangor, Malaysia
}

(Received June 24, 2019)

\begin{abstract}
Summary Vitamin A deficiency is common in many countries where rice is the staple food. Food fortification is an important strategy to address this problem. As rice noodle is the second principal form of rice products widely consumed in Asia, rice noodles could be a potential vehicle for fortification of vitamin A. In this study, rice noodles were prepared from 0, 300, 600, 1,050, and 1,500 $\mu \mathrm{g}$ of vitamin A per $100 \mathrm{~g}$ of rice flour. Samples were analyzed for quality, sensory evaluation, and enhancement of vitamin A intakes. Increasing level of vitamin A fortification did not influence quality and sensory properties of the rice noodles, except for the ash content, color, and appearance of the noodles. Rice noodle that was fortified with the highest level of vitamin A was found to be the darkest in color. However, this sample received scores higher than 6 (like slightly) for appearance. Furthermore, sample fortified with the highest level of vitamin A produced rice noodles with the highest level of vitamin A retention suggesting that noodles were good vehicle for vitamin A fortification. Fortification of rice flour with $1,500 \mu \mathrm{g}$ of vitamin A produced rice noodles with $24.88 \%$ of the RDI for vitamin A per serving and provided an effective means of enhancing vitamin A intake.
\end{abstract}

Key Words rice noodles, vitamin A fortification, quality, sensory evaluation, intake

Despite its wide consumption by the world population, rice is proven to be related to micronutrient deficiency among people in rice consuming countries, particularly vitamin A deficiency (VAD). VAD is a major public health nutrition problem, affecting an estimated 190 million preschool-aged children and 19 million pregnant and lactating women globally, and 83 million adolescents in Southeast Asia (1). According to World Health Organization (WHO) mortality data, around 0.8 million deaths can be attributed to VAD each year (2).

Nearly half of all the VAD occur in South and South East Asia and Africa (3). Its consequences (disorders) include xerophthalmia (the leading cause of early childhood blindness), increased severity of infection, anemia, and death. VAD is largely due to chronic dietary insufficiency of vitamin A. A low intake of preformed retinol from animal source foods and a low supply of pro-vitamin carotenoids from plant foods affected more than 5 million preschool children worldwide and nearly 10 million pregnant women with night blindness, and 200 million individuals in these population groups have subclinical vitamin A deficiency (4).

Food-based strategies such as dietary diversification, food fortification, and supplementation are the best way of preventing micronutrient malnutrition. In addition,

E-mail: nura_malahayati@yahoo.com food fortification has been recognized by many national governments as an important strategy to help improve the health and nutritional status of millions of people on a continuous and self-sustaining basis. Fortification can often be implemented and sustained over a long period, making it to be the most cost-effective way to overcome micronutrient malnutrition $(5,6)$. Previous experiences have shown that fortification is technologically and economically effective for increasing micronutrient intakes in population (7).

Previous studies proved that food product have been fortified with vitamin A such as oil (8), margarine (9), wheat flour pandesal $(10)$, sugar $(11,12)$, and monosodium glutamate (13) substantial improvement in vitamin A status of the target group.

Rice noodle is one of widely consumed food products is potentially the most cost-effective method of fighting widespread vitamin A deficiency. This rice noodle holds great promise for elevating VAD in population that consume rice-based diets especially in Southeast Asian countries. However, as expected, there were some vitamin A losses that occurred during the rice noodles processing. In this study, an evaluation on the impact of increasing the levels of vitamin A on the cooking quality, vitamin A retention, and sensory characteristics of the rice noodle was carried out. 
Table 1. Effect of different levels of vitamin A on chemical compositions of rice noodle.

\begin{tabular}{ccccc}
\hline $\begin{array}{c}\text { Level of vitamin A } \\
(\mu \mathrm{g} / 100 \text { g flour })\end{array}$ & $\begin{array}{c}\text { Moisture } \\
(\%)\end{array}$ & $\begin{array}{c}\text { Ash } \\
(\%)\end{array}$ & $\begin{array}{c}\text { Protein } \\
(\%)\end{array}$ & $\begin{array}{c}\text { Fat } \\
(\%)\end{array}$ \\
\hline 0 & $10.28 \pm 0.03^{\mathrm{a}}$ & $0.31 \pm 0.01^{\mathrm{a}}$ & $7.67 \pm 0.04^{\mathrm{a}}$ & $0.03 \pm 0.01^{\mathrm{a}}$ \\
300 & $10.22 \pm 0.16^{\mathrm{a}}$ & $0.34 \pm 0.07^{\mathrm{b}}$ & $7.64 \pm 0.01^{\mathrm{a}}$ & $0.04 \pm 0.00^{\mathrm{a}}$ \\
600 & $10.42 \pm 0.28^{\mathrm{a}}$ & $0.49 \pm 0.03^{\mathrm{c}}$ & $7.63 \pm 0.00^{\mathrm{a}}$ & $0.04 \pm 0.02^{\mathrm{a}}$ \\
1,050 & $10.28 \pm 0.10^{\mathrm{a}}$ & $0.59 \pm 0.01^{\mathrm{d}}$ & $7.65 \pm 0.01^{\mathrm{a}}$ & $0.03 \pm 0.00^{\mathrm{a}}$ \\
1,500 & $10.31 \pm 0.12^{\mathrm{a}}$ & $1.04 \pm 0.02^{\mathrm{e}}$ & $7.65 \pm 0.02^{\mathrm{a}}$ & $0.04 \pm 0.01^{\mathrm{a}}$ \\
\hline
\end{tabular}

Values are presented as means \pm standard deviations of triplicate determinations.

Means for each characteristic followed by the same superscript within the same column are not significantly different at $p<0.05$ by LSD test.

\section{MATERIALS AND METHODS}

Malaysian rice variety (MR 219) was procured from a local supermarket Selangor province, Malaysia.

Fortified rice flour preparation. Rice grains were drymilled using a rice miller (Good and Well, Malaysia) and were passed through a $\leq 63 \mu \mathrm{m}$ sieve using a sieving machine (Fritsch Analysette 3, Germany). Rice flour was fortified with the dry blended premix at the level of $0,300,600,1,050$, and 1,500 $\mu \mathrm{g}$ of vitamin A (Fortitech Asia Pacific Sdn. Bhd., Malaysia) per $100 \mathrm{~g}$ of rice flour. In a closed plastic bottle, rice flour and premix were mixed by shaking evenly for $30 \mathrm{~min}$. The fortified rice flour samples were packed in airtight plastic bags and stored at $4^{\circ} \mathrm{C}$ until used.

Fortified rice noodle preparation. The method of processing rice noodle in laboratory was adopted from home industries with some modifications. All the steps in the preparation of rice noodle were carried out in subdued lighting condition in order to minimize light destruction of the fortificants. Fortified rice flour was mixed with boiled water. The amount of boiled water added was $60 \%$ of the total weight of the dough formed. The mixture was kneaded until the dough was well homogenized. The kneaded dough was extruded through the holes ( $3 \mathrm{~mm}$ in diameter) of a cylindrical shaped mould. The extruded noodle was boiled in water until it floats (10 min) and then transferred into cooled water and strained. The noodle processed with the aforementioned method was identified as fresh rice noodle $(\mathrm{RN})$. A portion of the $\mathrm{RN}$ was dried at $40^{\circ} \mathrm{C}$ until $10-12 \%$ of final moisture content was achieved (about $12 \mathrm{~h}$ ) and the noodle was termed as dried rice noodle (DRN). Then, a portion of the DRN was cooked (boiled) for $10 \mathrm{~min}$ prior to consumption and labelled as cooked rice noodle (CRN).

Chemical composition analyses of rice noodles. Ash and moisture contents were determined using the AOAC methods 923.03 and 925.10, respectively (9). Total fat was determined with FOSS Soxtec Automated System 2050 (FOSS, Sweden) which complied with AOAC method 920.85 (14). Total protein was determined using Kjeldahl method based on AOAC method 920.87 (14).

Vitamin A determination of rice noodles. Vitamin A as retinol contents of fortified rice flour (FRF) and rice noodle samples (RN, DRN, and CRN) were determined using a high pressure liquid chromatograph (HPLC) (Agilent Technologies, 1200 series, USA) according to AACC method 86-06 (15).

Color determination of rice noodles. The color of rice noodle samples was measured using a Hunter $L^{*} a^{*} b^{*}$ spectrophotometer (UltraScan PRO D65, USA). The three axes, $L^{*}, a^{*}$, and $b^{*}$ are defined respectively as lightness $($ dark $=0$ to light $=100)$, the tendency from green $(-)$ to red $(+)$ and the tendency from blue $(-)$ to yellow $(+)$. The integrated color difference $\left(\Delta E^{*}\right)$ was then calculated as the sum of the differences of the $L^{*}$, $a^{*}$, and $b^{*}$ values of the rice noodle samples from the control (unfortified rice noodle).

Sensory evaluation of rice noodles. Sensory evaluation of CRN samples was carried out with 50 panelists comprising of students and staff (age range 18-35 y old) at the Faculty of Food Science and Technology, Universiti Putra Malaysia in the sensory laboratory. Panelists were required to evaluate the aroma, appearance, taste, texture, and overall acceptability of the CRN using the 9-point hedonic scale.

Stastistical analysis. All analyses were performed in triplicates. Data were subjected to analysis of variance (ANOVA) followed by the least significant difference test (LSD) to compare treatment means at significant level of $95 \%(p<0.05)$ by using SPSS software version 19.

\section{RESULTS}

Effect of different levels of vitamin A on chemical compositions of rice noodle

The effect of different levels of vitamin A on chemical compositions of rice noodle samples was presented in Table 1. Fortification had no significant effect on the moisture, protein and fat contents of the rice noodle samples. However, the addition of different levels of vitamin A influenced the ash content of the rice noodles. The ash content of the rice noodle samples increased with an increase in the vitamin A level $(p<$ $0.05)$.

Effect of different levels of vitamin A on rice noodle color

There was a significant effect of increasing vitamin A level specifically on the lightness $\left(L^{*}\right)$ of rice noodles $(p<$ 0.05) (Table 2). Noodles with the highest vitamin A 
Table 2. Effect of different levels of vitamin A on rice noodle color.

\begin{tabular}{|c|c|c|c|c|}
\hline $\begin{array}{l}\text { Level of vitamin A } \\
(\mu \mathrm{g} / 100 \mathrm{~g} \text { flour })\end{array}$ & $L^{*}$ & $a^{*}$ & $b^{*}$ & $\Delta E^{*}$ \\
\hline 0 & $89.73 \pm 0.01^{\mathrm{a}}$ & $-0.06 \pm 0.03^{\mathrm{a}}$ & $8.26 \pm 0.07^{\mathrm{a}}$ & \\
\hline 300 & $89.51 \pm 0.48^{\mathrm{ab}}$ & $-0.08 \pm 0.01^{\mathrm{a}}$ & $8.55 \pm 0.51^{\mathrm{a}}$ & 0.36 \\
\hline 600 & $89.09 \pm 0.53^{\mathrm{ab}}$ & $-0.13 \pm 0.02^{b}$ & $8.65 \pm 0.23^{\mathrm{a}}$ & 0.75 \\
\hline 1,050 & $88.87 \pm 0.53^{\mathrm{b}}$ & $-0.14 \pm 0.02^{b}$ & $8.71 \pm 0.42^{\mathrm{a}}$ & 0.97 \\
\hline 1,500 & $88.06 \pm 0.65^{c}$ & $-0.14 \pm 0.01^{b}$ & $8.93 \pm 0.86^{\mathrm{a}}$ & 1.80 \\
\hline
\end{tabular}

Values are presented as means \pm standard deviations of triplicate determinations.

Means for each characteristic followed by the same superscript within the same column are not significantly different at $p<0.05$ by LSD test.

Table 3. Effect of different levels of vitamin A on vitamin A content $(\mu \mathrm{g} / 100 \mathrm{~g})$ at every stage of rice noodle processing.

\begin{tabular}{|c|c|c|c|c|}
\hline $\begin{array}{c}\text { Level of vitamin A } \\
(\mu \mathrm{g} / 100 \mathrm{~g} \text { flour })\end{array}$ & FRF & $\mathrm{RN}$ & DRN & CRN \\
\hline 0 & nd & nd & nd & nd \\
\hline 300 & $16.30 \pm 0.62^{\mathrm{a}}$ & $12.70 \pm 0.06^{\mathrm{a}}$ & $12.20 \pm 0.00^{\mathrm{a}}$ & $7.67 \pm 0.00^{\mathrm{a}}$ \\
\hline 600 & $99.94 \pm 0.59^{b}$ & $79.92 \pm 0.05^{b}$ & $79.50 \pm 0.06^{\mathrm{b}}$ & $50.19 \pm 0.09^{b}$ \\
\hline 1,050 & $203.42 \pm 3.22^{\mathrm{c}}$ & $163.32 \pm 0.08^{c}$ & $159.59 \pm 0.21^{\mathrm{c}}$ & $98.54 \pm 0.59^{c}$ \\
\hline 1,500 & $304.91 \pm 2.59^{\mathrm{d}}$ & $240.06 \pm 3.08^{\mathrm{d}}$ & $233.34 \pm 0.30^{\mathrm{d}}$ & $126.02 \pm 0.79^{d}$ \\
\hline
\end{tabular}

Values are presented as means \pm standard deviations of triplicate determinations.

Means for each characteristic followed by the same superscript within the same column are not significantly different at $p<0.05$ by LSD test.

nd $=$ not detectable.

$\mathrm{FRF}=$ fortified rice flour; $\mathrm{RN}=$ fresh rice noodle; $\mathrm{DRN}=$ dried rice noodle; $\mathrm{CRN}=$ cooked rice noodle.

level was the darkest, as indicated by the lowest $L^{*}$ value and/or highest $\Delta E^{*}$. Moreover, rice noodle samples with different added levels of vitamin A had negative $a^{*}$ values (greenish shades) and positive $b^{*}$ values (yellowish shades). The $a^{*}$ and $b^{*}$ values ranged from -0.08 to -0.14 and 8.55 to 8.93 , respectively for fortified noodles which were greater than that of unfortified noodle $(0 \mu \mathrm{g} / 100 \mathrm{~g})$. The $a^{*}$ and $b^{*}$ values of the rice noodles increased with an increase in the levels of vitamin A.

Effect of different levels of vitamin A content at every stage of rice noodle processing

Table 3 showed that vitamin A was undetectable in $\mathrm{RN}, \mathrm{DRN}$ and CRN that were not fortified $(0 \mu \mathrm{g} / 100 \mathrm{~g})$. Vitamin A content of RN, DRN and CRN increased significantly as a result of increasing the levels of the vitamin A fortification. The mean retention of vitamin A the rice noodle samples decreased from 100\% in FRF to $65.60 \pm 3.16 \%$ in $\mathrm{RN}, 58.89 \pm 4.96 \%$ in DRN and $19.97 \pm 1.10 \%$ in CRN. The loss of vitamin A at every stage of the rice noodle processing was significant.

In order to evaluate fortified rice noodles as a potential source of vitamin A, the vitamin A retention in $\mathrm{RN}$ and CRN was presented in a manner that would facilitate the comparison with the Recommended Dietary Allowances (RDA) values of the micronutrients (Table $4)$. For unfortified rice flour $(0 \mu \mathrm{g} / 100 \mathrm{~g})$, the amount of vitamin A in RN and CRN were not detectable. Therefore, unfortified rice noodle is not a good source of vita- $\min$ A.

The health claim regulation of fortified product criterion that product must contain at least $15 \%$ of the RDI for the specific nutrient per serving of food (16). Based on this regulation, $\mathrm{RN}$ prepared from fortified rice flour with all levels vitamin A studied provided an effective means of enhancing vitamin A intake. Furthermore, fortification of rice flour with $1,050 \mu \mathrm{g}$ and $1,500 \mu \mathrm{g}$ of vitamin A per $100 \mathrm{~g}$ of flour produced CRN with $18.06 \%$ and $24.90 \%$ of the RDA for vitamin A per serving. This CRN can be an effective source of vitamin A and can be used to supply vitamin A in the diet.

Effect of different levels of vitamin A on sensory characteristics of rice noodle

Sensory characteristics in terms of aroma, appearance, taste, texture, and overall acceptability of rice noodles as affected by increasing levels of vitamin A are presented in Table 5.

The increase in the vitamin A level significantly affected the appearance of the rice noodles $(p<0.05)$ but had no effect on the aroma, taste, texture, and overall acceptability of the rice noodles. These results were in good agreement with that of Misaki and Yasumatsu (17). The authors stated that a number of sensory studies conducted in Japan on Shingen enriched rice showed that the addition of nutrients did not affect the appearance, aroma, or taste of the cooked rice. 
Table 4. Contribution of fresh rice noodles (RN) and cooked rice noodle (CRN), prepared from rice flours with different levels of folic acid, to dietary intakes.

\begin{tabular}{|c|c|c|c|c|}
\hline \multirow[b]{2}{*}{$\begin{array}{l}\text { Level of folic acid } \\
\qquad(\mu \mathrm{g} / 100 \mathrm{~g})\end{array}$} & \multicolumn{2}{|c|}{$\mathrm{RN}$} & \multicolumn{2}{|c|}{ CRN } \\
\hline & $\begin{array}{l}\text { Content } \\
\mu \mathrm{g} / \mathrm{serving}\end{array}$ & $\begin{array}{l}\text { Proportion of } \\
\text { RDA in } \\
1 \text { serving (\%) }\end{array}$ & $\begin{array}{l}\text { Content } \\
\mu \mathrm{g} / \text { serving }\end{array}$ & $\begin{array}{l}\text { Proportion of } \\
\text { RDA in } \\
1 \text { serving }(\%)\end{array}$ \\
\hline 0 & nd & nd & nd & nd \\
\hline 16 & 7.32 & 1.83 & 4.42 & 1.11 \\
\hline 100 & 46.08 & 11.52 & 28.93 & 7.23 \\
\hline 200 & 94.15 & 23.54 & 56.81 & 14.20 \\
\hline 300 & 138.39 & 34.60 & 72.65 & 18.16 \\
\hline
\end{tabular}

nd $=$ not detectable.

One serving of fresh rice noodles corresponds to $57.65 \mathrm{~g}$ of total consumed rice-based noodles (Malaysian Ministry of Health, 2006).

$\mathrm{RDA}=$ Recommended Dietary Allowances of the Food and Nutrition Board of the US Institute of Medicine for adult reference women (2001).

Table 5. Effect of different levels of folic acid on mean of hedonic scales for panelists' acceptance of rice noodle.

\begin{tabular}{|c|c|c|c|c|c|}
\hline $\begin{array}{l}\text { Level offolic acid } \\
\qquad(\mu \mathrm{g} / 100 \mathrm{~g})\end{array}$ & Aroma & Appearance & Taste & Texture & $\begin{array}{c}\text { Overall } \\
\text { acceptability }\end{array}$ \\
\hline 0 & $6.00 \pm 1.69^{a}$ & $6.88 \pm 1.33^{b}$ & $5.53 \pm 1.55^{\mathrm{a}}$ & $5.30 \pm 1.46^{\mathrm{a}}$ & $6.54 \pm 1.34^{\mathrm{a}}$ \\
\hline 16 & $6.58 \pm 1.39^{a}$ & $7.56 \pm 1.07^{\mathrm{c}}$ & $5.96 \pm 1.70^{\mathrm{a}}$ & $5.34 \pm 1.39^{a}$ & $6.36 \pm 1.11^{\mathrm{a}}$ \\
\hline 100 & $6.56 \pm 1.59^{\mathrm{a}}$ & $7.56 \pm 1.07^{\mathrm{c}}$ & $6.52 \pm 1.40^{\mathrm{a}}$ & $5.28 \pm 1.65^{\mathrm{a}}$ & $5.98 \pm 1.66^{\mathrm{a}}$ \\
\hline 200 & $6.50 \pm 1.39^{\mathrm{a}}$ & $5.30 \pm 1.76^{\mathrm{a}}$ & $5.26 \pm 1.48^{\mathrm{a}}$ & $5.22 \pm 1.61^{\mathrm{a}}$ & $6.22 \pm 1.45^{\mathrm{a}}$ \\
\hline 300 & $6.60 \pm 1.43^{\mathrm{a}}$ & $6.20 \pm 1.55^{b}$ & $6.12 \pm 1.18^{\mathrm{a}}$ & $5.52 \pm 1.76^{\mathrm{a}}$ & $6.58 \pm 1.31^{\mathrm{a}}$ \\
\hline
\end{tabular}

Values are means \pm standard deviations; $n=50$. The 9-point hedonic scale with: $1=$ dislike extremely, $2=$ dislike very much, $3=$ dislike moderately, $4=$ dislike slightly, $5=$ neither like nor dislike, $6=$ like slightly, $7=$ like moderately, $8=$ like very much, and $9=$ like extremely.

Means for each characteristic followed by the same superscript within the same column are not significantly different at $p<0.05$ by LSD test.

\section{DISCUSSION}

The significantly higher ash content of the rice noodle samples with an increase in the vitamin A level (Table 1) confirmed these findings and indicated that the highest level of vitamin A contained the highest vitamin A residue.

Rice noodle prepared from flour which was fortified with the highest level of vitamin A was found to be the darkest (Table 2). This was caused by the discoloration of vitamin A resulted in dark color of fortified rice noodles.

The loss of vitamin A at every stage of the rice noodle processing was significant (Table 3). Vitamin is very labile in the processing environment. The loss of vitamin A during the rice noodle processing was due to oxidative damage since vitamin $\mathrm{A}$ is oxygen and temperature sensitive. This result was in good agreement with that of Li et al. (18) who stated that oxidative degradation caused by free-radical attack on the vitamin A molecule. Losses were the highest during the noodles were cooked in boiling water. This might be because of vitamin A that rapidly loses its activity when heated in the presence of oxygen, especially at higher temperatures.

The results obtained in this study were supported by findings of previous research on instant wheat noodles. Compared with a control product which contained about one-half of the vitamin A and iron in the fortified product, consumption of the instant noodles fortified with $750 \mu \mathrm{g}(2,500 \mathrm{IU})$ of vitamin A and $9 \mathrm{mg}$ of iron per $100 \mathrm{~g}$ for $3 \mathrm{mo}$ had a beneficial effect on vitamin A and iron status of pregnant women and children under $5 \mathrm{y}$ of age (13). Another research report on instant noodles, a non-staple food, suggested that multiple micronutrient (vitamin $\mathrm{A}, \mathrm{B}_{1}, \mathrm{~B}_{2}$, niacin, folic acid and iron) fortification level of $10-30 \%$ of the RDA per serving (typically about one package of $55 \mathrm{~g}$ ) can complement well any existing fortification of staple foods (19).

Rice noodles prepared using the flour with the highest level of vitamin A $(1,500 \mu \mathrm{g} / 100 \mathrm{~g})$ (Table 5) were awarded higher scores for aroma, taste, texture, and overall acceptability as compared to the unfortified rice noodle $(0 \mu \mathrm{g} / 100 \mathrm{~g})$. This indicated that the increased level of vitamin A in the noodles still preserved the sensory appeal of the noodles. 
Disclosure of state of COI

Authors declare that they have no conflict of interest.

\section{REFERENCES}

1) Klemm RD, West KP Jr, Palmer AC, Johnson Q, Randall P, Ranum P, Northrop-Clewes C. 2010. Vitamin A fortification of wheat flour: considerations and current recommendations. Food Nutr Bull 31(1 Suppl): S47-S61.

2) WHO. 2002. The World Health Report 2002: Reducing Risks, Promoting Healthy Life: overview. Geneva: WHO.

3) Bhutta ZA. 2008. Micronutrient needs of malnourished children. Curr Opin Clin Nutr Metab Care 11: 309-314.

4) WHO. 2009. Global Prevalence of Vitamin A Deficiency in Population at Risk 1995-2005. WHO Global Database on Vitamin A Deficiency. Geneva: WHO.

5) WHO/FAO. 2006. Guidelines on Food Fortification with Micronutrients. Geneva: WHO.

6) Wesley A, Ranum P. 2004. Fortification handbook: Vitamin and Mineral Fortification of Wheat Flour and Maize Meal. The Micronutrient Initiative.

7) Lotfi M, Mannar MGV, Merx RJHM, Naber-van den, Heuvel P. 1996. Micronutrient Fortification of Foods, Current Practices, Research, and Opportunities: Iron, Vitamin A, Iodine. The Micronutrient Initiative (MI)/ International Agriculture Center (IAC). Ottawa, Ontario, Canada.

8) Favaro RMD. 1992. Evaluation of the effect of heat treatment on the biological value of vitamin A fortified soybean oil. Nutr Res 12: 1357-1363.

9) Solon FS. 1997. A cace report on the fortification of margarine with vitamin A: The Phillippine experience. In: Food Fortification to End Micronutrient Malnutrition State of The Art, p 32-36. The Micronutrient Initiative, International Development Research Centre, Ottawa, Canada.
10) Solon FS, Klemm RD, Sanchez L, Darnton-Hill I, Craft NE, Christian P, West KP, Jr. 2000. Efficacy of a vitamin A-fortified wheat-flour bun on the vitamin A status of Filipino schoolchildren. Am J of Clin Nutr 72(3): 738744.

11) Arroyane G, Mejla LA, Agullar JR. 1981. The effect of vitamin A fortification of sugar on the serum vitamin A levels of preschool Guatemalan children: A longitudinal evaluation. Am J Clin Nutr 34: 41-49.

12) Dary O. 1997. Sugar fortification with vitamian A: A central American contribution to developing world. In: Food Fortification to End Micronutrient Malnutrition State of The Art, p 95-98. The Micronutrient Initiative, International Development Research Centre, Ottawa, Canada.

13) Muhilal. 1988. Noodles: A suitable vehicle for fortification. Nutr Rev 95: 2-6.

14) AOAC. 2005. Official Methods of Analysis of the AOAC International. 16th ed., supplement 1998. Washington, DC: AOAC

15) AACC. 2003. Amercan Association of Cereal Chemists: Approved Methods. St. Paul, MN: AACC.

16) FAO/WHO. 2005. World Health Organization Guidelines on Food Fortification with Micronutrients for the Control of Micronutrient Malnutrition. Geneva: WHO.

17) Misaki M, Yasumatsu K. 1985. Rice Enrichment and Fortification. s: B.O. Juliano (ed.) Rice Chemistry and Technology. Minnesota: AACC.

18) Li YO, Lam J, Diosady LL, Jankowski S. 2009. Antioxidant system for preservation of vitamin A in Ultra Rice. Food Nutr Bull 30: 82-89.

19) USAID and DSM. 2001. Fortification basics. Instant noodles: A potential Vehicle for Micronutrient Fortification. 